\title{
PERMASALAHAN-PERMASALAHAN YANG DIHADAPI SEKOLAH PENYELENGGARA PENDIDIKAN INKLUSI PADA TINGKAT SD
}

\author{
Nissa Tarnoto \\ Fakultas Psikologi, Universitas Ahmad Dahlan, Jl. Kapas No 9, Semaki Yogyakarta \\ nissa.tarnoto@psy.uad.ac.id.
}

\begin{abstract}
The declaration of inclusive education that focus to facilitate the educational needs of children with special needs (ABK) has been running in many area in Indonesia, especially in big cities such as Jakarta, Yogyakarta, Surabaya, Malang. However, many problems rose for it's implementation. This study aims to determine the problems experienced by the teachers and schools using qualitative metode and indigenous approach that involved 112 teachers from 18 inclusive schools in Yogyakarta as subjects. Data was collected through open-ended questionnaire and was analyzed by coding techniques. The results showed a wide range of problems faced by the teachers and schools such as lack of competence in dealing with students with special needs, lack of parental awareness of children with special needs, the number of students with special needs in every class, lack of cooperation of various parties such as professional government and soceity.
\end{abstract}

Keyword: children with special needs, inclusion education, indigenous psychology

\begin{abstract}
Abstrak
Dicanangkannya pendidikan inklusi di Indonesia dengan tujuan untuk memfasilitasi kebutuhan pendidikan bagi anak berkebutuhan khusus (ABK) sudah banyak dijalankan di seluruh Indonesia khususnya kota-kota besar seperti Jakarta, Yogyakarta, Surabaya, Malang, tetapi dalam pelaksanannya menemukan banyak kendala-kendala atau permasalahan di sekolah khususnya bagi guru. Penelitian ini bertujuan untuk mengetahui permasalahanpermasalahan yang dialami guru dan sekolah dalam penyelengaraan pendidikan inklusi pada tingkat SD di wilayah Kota Yogyakarta. Subyek penelitian adalah guru yang mengajar di sekolah penyelenggara Pendidikan Inklusi. Data diperoleh melalui open-ended questionnaire (pertanyaan terbuka). Metode yang digunakan adalah kualitatif dengan analisis menggunakan teknik koding. Desain penelitian yang digunakan menggunakan pendekatan indigenous psychology bagian dari tradisi pendekatan ilmiah dimana aspek yang penting dalam pendekatan ini adalah usaha untuk menemukan metode yang sesuai untuk mengungkap fenomena dalam suatu investigasi. Hasil penelitian menunjukkan ada berbagai permasalahan yang ditemui guru terkait kesiapan sekolah itu sendiri seperti kurangnya kompetensi guru dalam menghadapi siswa $\mathrm{ABK}$, permasalahan terkait kurangnya kepedulian orangtua terhadap ABK, selain itu banyaknya siswa ABK dalam satu kelas, dan kurangnya kerjasama dari berbagai pihak seperti masyarakat, ahli professional dan pemerintah.
\end{abstract}

Kata Kunci: anak berkebutuhan khusus, pendidikan inklusi, indigenous psychology 


\section{Pendahuluan}

Meningkatnya jumlah Anak Berkubutuhan Khusus (ABK) di Indonesia dari tahun ke tahun semakin besar. Menurut data BPS tahun 2005 diperkirakan ada kurang lebih 4,2 juta ABK di Indonesia (Republika,2013). Berdasarkan data BPS tahun 2007 ada 8,3 juta ABK di Indonesia, sehingga dapat disimpulkan dari tahun ke tahun jumlah ABK semakin meningkat. Sebagian besar ABK belum mengeyam pendidikan. Berdasarkan UU No 20 tahun 2003, Pasal 5 menyatakan bahwa "Setiap warga negara mempunyai hak yang sama untuk mengeyam pendidikan, dan warga Negara yang memiliki kelainan fisik, emosional, intelektual, mental dan/atau sosial berhak memperoleh pendidikan khusus".

Pemerintah Indonesia sendiri berusaha memfasilitasi kebutuhan pendidikan bagi ABK dengan diselenggarakannya sekolah luar Biasa (SLB) yang sudah tersebar ke seluruh wilayah Indonesia, tetapi jika dibandingkan jumlah ABK yang semakin tahun semakin meningkat jumlahnya, maka jumlah SLB tidak bisa menampung ABK. Berkaitan dengan masalah tersebut dan terkait UU no 20 tahun 2003, pemerintah Indonesia telah melaksanakan pendidikan inklusi untuk memfasilitasi dan memberikan hak kepada anak-anak berkubutuhan khusus. Tahun 2001, pemerintah mulai melakukan uji coba perintisan sekolah inklusi di daerah Istimewa Yogyakarta dan daerah Ibu Kota Jakarta. Tahun 2004, Pemerintah Indonesia melalui deklarasi di Bandung mengumumkan secara resmi program "Indonesia Menuju Pendidikan Inklusif”, tetapi dalam pelaksanaan masih ditemukan banyak kendala dibeberapa kota seperti seperti, manajemen sekolah inklusi masih belum optimal, tenaga kerja yang memiliki kapabilitas dalam mengajar anakanak ABK masih dinilai kurang (seperti guru belum mengetahui karateristik ABK dan metode-metode untuk menanganinya), kurangnya guru pendamping kelas, belum siapnya sekolah menampung ABK, masih banyaknya siswa dalam kelas, masih adanya intimidasi anak $\mathrm{ABK}$ oleh teman sekelasnya (Kompas, 2012)

Secara konseptual akademik inklusi diartikan dengan integrasi yang menyeluruh untuk semua siswa tanpa terkecuali siswa dengan kebutuhan khusus dalam kelas regular yang disesuaikan dengan umur siswa dan letak sekolah (Bélanger dalam Schmidt dan Venet 2012). Pendidikan inklusi adalah sistem pengajaran yang pelaksanaannya menggabungkan anak berkebutuhan khusus dengan anak normal dan menggabarkan separuh atau seluruh waktu belajar siswa berkebutuhan khusus dalam kelas regular, dimana lingkungan sekolah memberi kebebasan untuk mendukung anak berkebutuhan khusus (eripek, 2007 dan Kircal-Iftar, 1998 dalam Sadioglu, Batu, Bilgin, dan Oksal, 2013).

Di Indonesia, pendidikan inklusif secara resmi didefinisikan sebagai berikut:

Pendidikan inklusi dimaksudkan sebagai sistem layanan pendidikan yang mengikutsertakan anak berkebutuhan khusus belajar bersama dengan anak sebayanya di sekolah reguler yang terdekat dengan tempat tinggalnya. Penyelenggaraan pendidikan inklusif menuntut pihak sekolah melakukan penyesuaian baik dari segi kurikulum, sarana dan prasarana pendidikan, maupun sistem pembelajaran yang disesuaikan dengan kebutuhan individu peserta didik (Direktorat PSLB, 2004). 
Berdasarkan Pasal 1 Peraturan Menteri Pendidikan Nasional RI Nomor 70 Tahun 2009 tentang Pendidikan Inklusif Bagi Peserta Didik yang Memiliki Kelainan dan Memiliki Potensi Kecerdasan dan/atau Bakat Istimewa, disebutkan bahwa:

Pendidikan inklusif adalah sistem penyelenggaraan pendidikan yang memberikan kesempatan kepada semua peserta didik yang memiliki kelainan dan memiliki potensi kecerdasan dan/atau bakat istimewa untuk mengikuti pendidikan atau pembelajaran dalam satu lingkungan pendidikan secara bersama-sama dengan peserta didik pada umumnya.

Sedangkan dalam pasal 2 peraturan tersebut dijelaskan bahwa Pendidikan inklusif bertujuan:

(1) memberikan kesempatan yang seluas-luasnya kepada semua peserta didik yang memiliki kelainan fisik, emosional, mental, dan sosial atau memiliki potensi kecerdasan dan/atau bakat istimewa untuk memperoleh pendidikan yang bermutu sesuai dengan kebutuhan dan kemampuannya; (2) mewujudkan penyelenggaraan pendidikan yang menghargai keanekaragaman, dan tidak diskriminatifbagi semua peserta didik

Implikasi suksesnya program inklusi adalah adanya guru yang mengakomodasi dan memberi dukungan untuk kebutuhan semua siswa dalam kelas, tidak terlalu banyak paksaan dan tidak mengurangi hak siswa (Bélanger dan Maertens, 2004). Sesuai dengan model Bronfenbrenner's ecological perkembangan anak adalah hasil dari interaksi yang beragam dengan lingkungan dekat mereka, yaitu: microsistem yang berbeda (spt keluarga dan sekolah) yang salah satunya dapat memberikan atribusi untuk suksesnya atau kegagalan dari sekolah inklusi. Anak juga dipengaruhi oleh: a) Interaksi sosial antara dua atau lebih mikrosistem seperti relasi antara keluarganya dan sekolahnya. b). Relasi antara satu mikrosistem dan system yang lain, yang tidak termasuk ekosistem seperti hubungan antara sekolahnya dengan dewan pengurus sekolah dan c). masyarakat dimana dia tinggal atau makrosistem yang dipengaruhi oleh budaya, institusi, wilayah dan sebagainya dimana anak tumbuh. Dari sudut ini, akan menjadi mungkin untuk dianalisis prinsip penting yang berkenaan dengan masa depan anak. Siswa juga dipengaruhi oleh makrosistem dari pemerintah. Ada beberapa yang memegang otoritas yang memegang peranan penting dalam suksesnya implementasi di sekolah inklusi, apakah itu dari point managerial atau point filosofi (Beaupré et al. Bélanger, Collins \& White, Guzmán, Ingram, Parent, Praisner, dalam Schmidt dan Venet 2012).

Sekolah yang menyelenggarakan pendidikan inklusi di provinsi Yogyakarta tersebar diberbagai wilayah seperti di Kabupaten Gunung Kidul ada 239 sekolah yang menyelenggarakan pendidikan inklusi (217 SD, 20 SMP dan 1 SMA), di kota yogya terdapat 20 sekolah (SD-SMA), sementara di kabupaten Bantul dan Sleman akan segera ditetapkan ditahun ajaran 2011/2012 (DEPDIKNAS DIY, 2011). Data yang didapatkan peneliti ada 10-15 sekolah inklusi yang ada didaerah bantul dan sleman. Di Yogyakarta sendiri, pelaksanaan sekolah inklusi masih banyak mengalami persoalan seperti: Sumber Daya Manusia dan fasilitas masih terbatas serta penanaman yang kurang kepada siswa lain untuk dapat menerima ABK (HarianJogya, 2013).

Di Indonesia, inklusi memberi 
kesempatan kepada anak berkelainan dan anak yang lainya yang selama ini tidak bisa sekolah karena berbagai hal yang menghambat mereka untuk mendapatkan kesempatan sekolah, seperti letak sekolah luar biasa yang jauh, harus bekerja membantu orangtua, dan sebab lainya seperti berada di daerah konflik atau terkena bencana alam (Sugiarmin dalam Smith (2012). Sekolah inklusi bertujuan untuk memberi kesempatan bagi seluruh siswa untuk mengoptimalkan potensinya dan memenuhi kebutuhan belajarnya melalui program pendidikan inklusi. Pendidikan inklusif ialah program pendidikan yang mengakomodasi seluruh siswa dalam kelas yang sama sesuai dengan usianya dan perkembangannya (Schmidt dan Venet, 2011). Pendidikan inklusi juga membuktikan bahwa mendidik anak dengan kebutuhan khusus bersama dengan anak normal menunjukkan perkembangan yang signifikan (Sadioglu, Batu, Bilgin, dan Oksal, 2013). Berdasarkan paparan diatas maka dapat disimpulkan bahwa dalam penyelenggaraan sekolah inklusi perlu adanya integrasi antara seluruh pihak yaitu dari pihak sekolah seperti manajemen sekolah (kurikulum, sarana prasarana yang mendukung), guru, siswa, orangtua, masyarakat dan pemerintah, sehingga pendidikan inklusi dapat berjalan dengan baik.

Pemerintah Indonesia perlu mensyukuri bahwa sejak digulirkannya pendidikan inklusi di Indonesia, sambutan dan apresiasi masyarakat sangat luar biasa, sehingga implementasinya tumbuh dan berkembang cepat di berbagai pelosok negeri. UNESCO menilai bahwa dalam penyelenggaraan pendidikan inklusi bagi ABK, Indonesia pada tahun 2007 menduduki ranking ke 58 dari 130 negara. Sayangnya, karena berbagi faktor, terutama kurangnya komitmen dan dukungan pemerintah, sehingga implementasinya belum menasional dan menyeluruh, sehingga ranking tersebut terus mengalami kemerosotan, pada tahun 2008 berada pada ranking ke 63 dan pada tahun 2009 berada pada ranking ke 71 (Kompas).

Peneliti tertarik untuk mengetahui lebih dalam masalah-masalah apa saja yang dihadapi sekolah khususnya terkait dengan penyelenggaraan pendidikan inklusi, sebagai upaya untuk memperoleh gambaran secara menyeluruh dan mendalam yang diperoleh dari persepsi guru yang berkaitan dengan kendala-kendala atau permasalahan yang dihadapi oleh sekolah maupun guru dalam penyelenggaraan sekolah inklusi. Hasil penelitian ini diharapkan dapat memberikan kontribusi bagi dunia pendidikan khususnya psikologi pendidikan dan memberi gambaran kepada pemerintah, masyarakat yang bergerak dan mendalami dunia pendidikan khususnya, tentang kendala-kendala yang dihadapi guru maupun pihak sekolah dalam penyelenggaraan pendidikan inklusi tingkat SD. Harapannya kendala-kendala atau hambatan-hambatan tersebut dapat dipetakan sesuai karateristiknya sehingga ke depan dapat diberikan intervensi yang sesuai.

\section{Metode Penelitian}

Penelitian ini menggunakan pendekatan yang diarahkan untuk mengupayakan indigenous. Kim dan Berry,1993 (dalam Kim, Shu Yang dan Kuo Hwang, 2010) mendefinisikan indigenous psychology adalah kajian ilmiah tentang perilaku atau pikiran manusia yang native (asli), yang tidak ditransportasikan dari wilayah lain, dan dirancang untuk masyarakatnya. Indigenous psychology menekankan penemuan fenomena dalam masyarakat sesuai dengan konteksnya. 
Indigenous psychology adalah bagian dari tradisi pendekatan ilmiah dimana aspek yang penting dalam pendekatan ini adalah usaha untuk menemukan metode yang sesuai untuk mengungkap fenomena dalam suatu investigasi. Indigenous psychology menggunakan analisis multi-methods (Kim \& Berry, 1993). Indigenous tidak menghalangi pada pemakaian metode tertentu. Indigenous psychology menganjurkan penggunaan berbagai metodologi seperti kualitatif, kuantitatif, eksperimental, komparatif, dan analisis filosofis. Hasil-hasil dari multiple methods seharusnya dintegrasikan untuk memberikan pemahaman yang lebih komprehensif tentang fenomena psikologis ((Kim \& Berry, 1993). Dalam penelitian ini peneliti menggunakan metode kualitatif dengan menggunakan analisis dengan teknik koding.

Data penelitian diambil dari guru sekolah-sekolah yang terdaftar sebagai sekolah inklusi yang ada di kota Yogyakarta. Peneliti mengambil subyek dari semua guru yang terlibat disekolah inklusi tingkat SD yang ada di kota Yogyakarta. Dari 22 sekolah yang ditunjuk oleh Dinas Pendidikan kota Yogya ada 4 sekolah yang tidak bersedia untuk diambil datanya karena beberapa alasan seperti: sudah terlibat MOU dengan lembaga lain, tidak merasa bahwa sekolah inklusi. Dari 18 Sekolah Inklusi tingkat SD yang bersedia di jadikan tempat penelitian hanya terkumpul 112 data dari guru.

Metode pengumpulan data dalam penelitian ini adalah dengan cara menyebar kuesioner berisi pertanyaan terbuka. Kuesioner ini disusun berdasarkan dari aspek apa yang diperlukan dalam suksesnya program pendidikan inklusi. Responden yang terdiri dari guru Sekolah Inklusi diminta untuk menjawab openended questionnaire (pertanyaan terbuka). Pertanyaan terbuka menurut Tukiran dkk.
(1989) adalah pertanyaan yang variasi jawabannya belum ditentukan terlebih dahulu sehingga responden mempunyai kebebasan untuk menjawab pertanyaan yang diajukan.

Data yang diperoleh dari pertanyaan terbuka akan memunculkan tema-tema. Menurut Hayes (dalam Kurniastuti, 2010) langkah yang digunakan untuk menganalisis tema-tema yang muncul itu adalah sebagai berikut: (a) menyiapkan data yang akan dianalisis, (b) mengidentifikasi informasi aitem yang spesifik yang nampak relevan dengan topik yang sedang diteliti, (c) memilah-milahkan data berdasar tema yang muncul, (d) memeriksa tema-tema yang muncul dan membuat formula definisi, (e) memberi perhatian pada masing-masing tema secara terpisah dan dengan hati-hati meninjau kembali masing-masing transkrif dengan material yang relevan dengan tema, (f) menggunakan seluruh bahan yang berhubungan dengan masing-masing tema untuk membuat konstruk, yang hasil akhirnya nanti berisi nama kategori dan definisi dengan data yang mendukung, dan (g) memilih data yang relevan untuk dijadikan ilustrasi dalam mendeskripsikan masing-masing tema.

Setelah data terkumpul dilakukan proses analisis data. Secara lebih rinci, proses analisis data akan dijelaskan dalam langkah-langkah berikut ini.

1. Memasukkan data kualitatif Memasukkan data yang berupa respon subyek ke progam computer yang dilakukan oleh asisten peneliti.

2. Kategorisasi Data Kualitatif

Kategorisasi dilakukan oleh peneliti bersama asisten peneliti. Kategorisasi dilakukan dengan cara semua respon didiskusikan terlebih dahulu untuk memperjelas dari maksud responden kemudian dicetak. Tahap selanjutnya 
adalah digunting. Guntingan-guntingan kertas yang berisi respon kemudian dikategorikan sesuai dengan tema kecilkecil yang muncul. Tahap selanjutnya tema-tema kecildimasukkan dalam kategori besar sesuai dengan teori yang ada dengan cara ditempel yang sesuai dengan tema yang ada. Untuk memastikan ketepatan tema, dilakukan ketgorisasi oleh peneliti dan asisten peneliti secara kelompok. Proses kategorisasi ini minimal harus disetujui oleh tiga orang untuk mengurangi subyektifitas.

Pada penelitian ini, peneliti membuat kategori jawaban, kemudian masingmasing kategori jawaban diberi kode angka (Tukiran, Handayani, \& Hagul, dalam Kurniastuti, 2010). Tahap pertama dalam mengkode, menurut Tukiran dkk (1989) adalah mempelajari jawaban responden, memutuskan perlu tidaknya jawaban tersebut dikategorikan terlebih dahulu dan memberikan kode pada jawaban yang ada.

3. Analisis Deskriptif Data Kualitatif Jawaban yang sudah dikategori kemudian di masukkan kembali oleh asisten peneliti dalam program Microsoft excel untuk diberi kode lebih lanjut untuk dibuat kategori superordinat,. Respon yang tidak masuk dalam kategori manapun dimasukkan dalam kategori lainnya.

\section{Hasil dan Pembahasan}

Penelitian ini menggunakan metode kualitatif. Data didapatkan dari hasil kategorisasi pertanyaan terbuka yang sudah dikoding. Hasil dari analisis dipaparkan dalam paparan hasil berikut ini. Permasalahan-permasalahan yang muncul dalam pelaksanaan sekolah inklusi berdasarkan persepsi dari guru, dalam hal : a. Guru.

Permasalahan-permasalahan yang muncul terkait guru berdasarkan kategori yang muncul, terdapat sepuluh kategori permasalahan yang diungkapkan guru. Permasalahan utama yang banyak dikeluhkan guru adalah kurangnya Guru Pendamping Kelas (GPK) sebesar 27,39\%, kurangnya kompetensi guru dalam menangani ABK sebanyak 19,64\%, guru kesulitan dalam Kegiatan Belajar Mengajar (KBM) sebanyak (17,86\%), kurangnya pemahaman guru tentang ABK dan Sekolah Inklusi sebanyak (16,67\%), latar belakang pendidikan guru yang tidak sesuai $(5,95 \%)$, beban administrasi yang semakin berat untuk guru $(5,36 \%)$, kurangnya kesabaran guru dalam menghadapi ABK $(2,39 \%)$ dan terakhir guru mengalami kesulitan dengan orangtua $(1,78 \%)$.

\section{b. Orangtua}

Permasalahan-permasalahan yang muncul terkait Orangtua yang paling banyak dikeluhkan oleh guru adalah: kepedulian orangtua terhadap penanganan ABK kurang $(47,27 \%)$, selanjutnya permasalahan yang muncul adalah pemahaman orangtua tentang ABK kurang $(41,21 \%)$, orangtua merasa malu sehingga menginginkan anaknya disekolah umum $(3,64 \%)$, toleransi dari orangtua siswa reguler terhadap $\mathrm{ABK}$ kurang $(3,64 \%)$, orangtua buta huruf $(2,42 \%)$, orangtua kurang sabar menangani $\mathrm{ABK}(1,21 \%)$, pengasuhan orangtua tunggal $(0,61 \%)$.

\section{c. Siswa}

Permasalahan-permasalahan yang muncul terkait siswa yang dikemukakan guru adalah: ABK dengan permasalahan berbeda dan memerlukan penanganan yang berbeda (35,29\%), ABK mengalami Kesulitan mengikuti materi pelajaran $(21,18 \%)$, sikap 
ABK yang belum bisa mengikuti aturan sehingga mengganggu proses KBM (20\%), permasalahan siswa regular terhadap ABK $(14,71 \%)$, dan permasalahan terakhir yang muncul terkait siswa adalah jumlah ABK yang melebihi Kuota dalam tiap kelasnya $(8,82 \%)$.

\section{d. Manajemen Sekolah}

Permasalahan-permasalahan yang muncul terkait Manajemen Sekolah yang dikemukakan oleh guru adalah: belum siapnya sekolah dengan program sekolah inklusi baik dari segi administrasi dan SDM (75\%), proses KBM yang belum berjalan maksimal $(17,86 \%)$, dan terakhir permasalahan yang muncul terkait orangtua adalah belum adanya program pertemuan rutin dengan orangtua yang diadakan sekolah $(7,14 \%)$.

\section{e. Pemerintah}

Permasalahan-permasalahan yang muncul terkait Pemerintah yang dikemukakan oleh guru adalah: perhatian dan kepedulian pemerintah terhadap pelaksanaan sekolah inklusi kurang (24.64\%), kebijakan terkait pelaksanaan sekolah inklusi belum jelas (21.74\%), belum adanya modifikasi kurikulum khusus sekolah inklusi (20.29\%), kurangnya pelatihan tentang pendidikan inklusi kepada guru (18.84\%), Perhatian pemerintah terhadap tenaga professional yang mendukung sekolah inklusi kurang baik dari segi jumlah dan kesejahteraannya $(10.87 \%)$, program yang dilakukan pemerintah belum berkelanjutan $(2.90 \%)$, belum ada lembaga khusus yang menangani pelatihan pendampingan $\mathrm{ABK}(0.72 \%)$.

\section{f. Masyarakat}

Permasalahan-permasalahan yang muncul terkait Masyarakat yang dikemukakan oleh guru adalah: minimnya pengetahuan masyarakat terkait pendidikan inklusi dan ABK (41.76\%), pandangan negatif masyarakat terhadap ABK dan sekolah inklusi, Kurangnya dukungan masyarakat terkait pelaksanaan inklusi (24.17\%).

\section{g. Lainnya}

Permasalahan-permasalahan yang muncul terkait yang lainnya adalah: kurangnya sarana dan prasarana yang mendukung pelaksanaan inklusi (87.10\%), kurangnya keterlibatan dari semua pihak (akademisi, tenaga ahli, guru, sekolah, orangtua, dan pemerintah) terkait pelaksanaan sekolah inklusi $(6,45 \%)$, latar belakang sosial yang mempengaruhi ABK $(3.23 \%)$, predikat sekolah inklusi membuat sekolah kehilangan siswa-siswa cerdas (1.61\%), belum ada kesepahaman tentang pelaksanaan inklusi antara berbagai pihak (1.61\%).

Permasalahan yang muncul antara satu dengan yang lain bila dikaji lebih lanjut akan saling berkaitan antara satu dengan yang lain, baik dari permasalahan guru, siswa, sekolah, masyarakat, maupun pemerintah. Pertama terkait permasalahan guru, guru mengeluhkan bahwa kurang kompetensi dalam menangani ABK. Hal ini disebabkan karena kurangnya pemahaman guru tentang ABK dan sekolah inklusi yang kemudian berdampak pada permasalahan yang muncul selanjutnya yaitu guru kesulitan dalam kegiatan belajar mengajar. Hal ini juga didukung dengan kenyataan bahwa ada beberapa guru yang memiliki latar pendidikan yang tidak sesuai dan kurangnya Guru Pendamping Kelas sehingga semakin menambah beban kerja guru yang berat baik beban administrasi maupun beban mengajar hal ini juga secara tidak langsung memberi dampak pada bagaimana guru menangani siswa di sekolah menjadi tidak maksimal, 
selain itu guru juga dihadapkan pada berbagai permasalahan ABK yang berbeda-beda dan memerlukan penanganan yang berbeda serta jumlah ABK yang melebihi kuota dalam tiap kelasnya sehingga berdampak pada kurang lancarnya proses KBM.

Beban guru semakin berat, pada saat menerima kenyataan dilapangan bahwa banyak dari orangtua $\mathrm{ABK}$ tidak peduli terhadap perkembangan anak nya. Banyak orangtua yang kemudian hanya pasrah sepenuhnya tentang perkembangan anak nya kepada sekolah. Hal ini juga bisa disebabkan karena pemahaman orangtua tentang ABK masih kurang. Permasalahan lain yang muncul yaitu toleransi atau pengertian dari orangtua siswa regular terhadap kebutuhan ABK masih kurang karena banyak dari masyarakat yang masih memandang rendah $\mathrm{ABK}$ dan sekolah inklusi sehingga masyarakat kurang memberi dukungan terkait pelaksanaan sekolah inklusi. Hal ini bisa disebabkan karena minimnya pengetahuan masyarakat yang terkait pendidikan inklusi dan ABK.

Hal tersebut membuat beban guru dan sekolah semakin berat, dimana secara umum, sekolah sendiri belum siap baik dari segi administrasi maupun SDM dalam pelaksanaan pendidikan inklusi disekolahnya, ditambah dengan kurangnya dukungan dan kerjasama dari semua pihak, kurangnya sarana prasarana yang disediakan pemerintah terkait pelaksanaan sekolah inklusi sehingga pelaksanaan sekolah inklusi tidak bisa berjalan maksimal.

Peneliti melihat bahwa permasalahanpermasalahan yang muncul sebenarnya dikarenakan baik sekolah, masyarakat dan guru belum sepenuhnya memahami dan mengetahui bagaimana cara menangani ABK pada khususnya. Hasil penelitian juga menunjukkan bahwa sekolah dan guru juga belum mengetahui bagaimana pelaksanaan sekolah inklusi yang sesuai dengan aturan yang ada. Hal ini dikarenakan Pemerintah dianggap kurang bisa mensosialisasikan kebijaksanan yang terkait dengan pelaksanaan sekolah inklusi atau kebijakan tentang sekolah inklusi sendiri belum jelas dan kurang nya pelatihan yang diadakan oleh Pemerintah yang bisa meningkatkan kompetensi guru. Guru menganggap bahwa perhatian dan kepedulian pemerintah terhadap sekolah inklusi kurang baik dari segi kesejahteraan SDM maupun terkait kompetensi SDM.

Hasil penelitian juga menunjukkan bahwa banyak berbagai masalah yang muncul terkait pelaksanaan sekolah inklusi dalam hal guru, siswa, orangtua, sekolah, masyarakat, pemerintah, sarana dan prasarana yang kurang, dan kurangnya kerjasama dari berbagai pihak sehingga berdampak kurang maksimalnya pelaksanaan sekolah inklusi yang ada.

Berikut Dinamika Permasalahan yang dikeluhkan guru terkait pelaksanaan sekolah inklusidapat dilihat pada gambar 1 . 


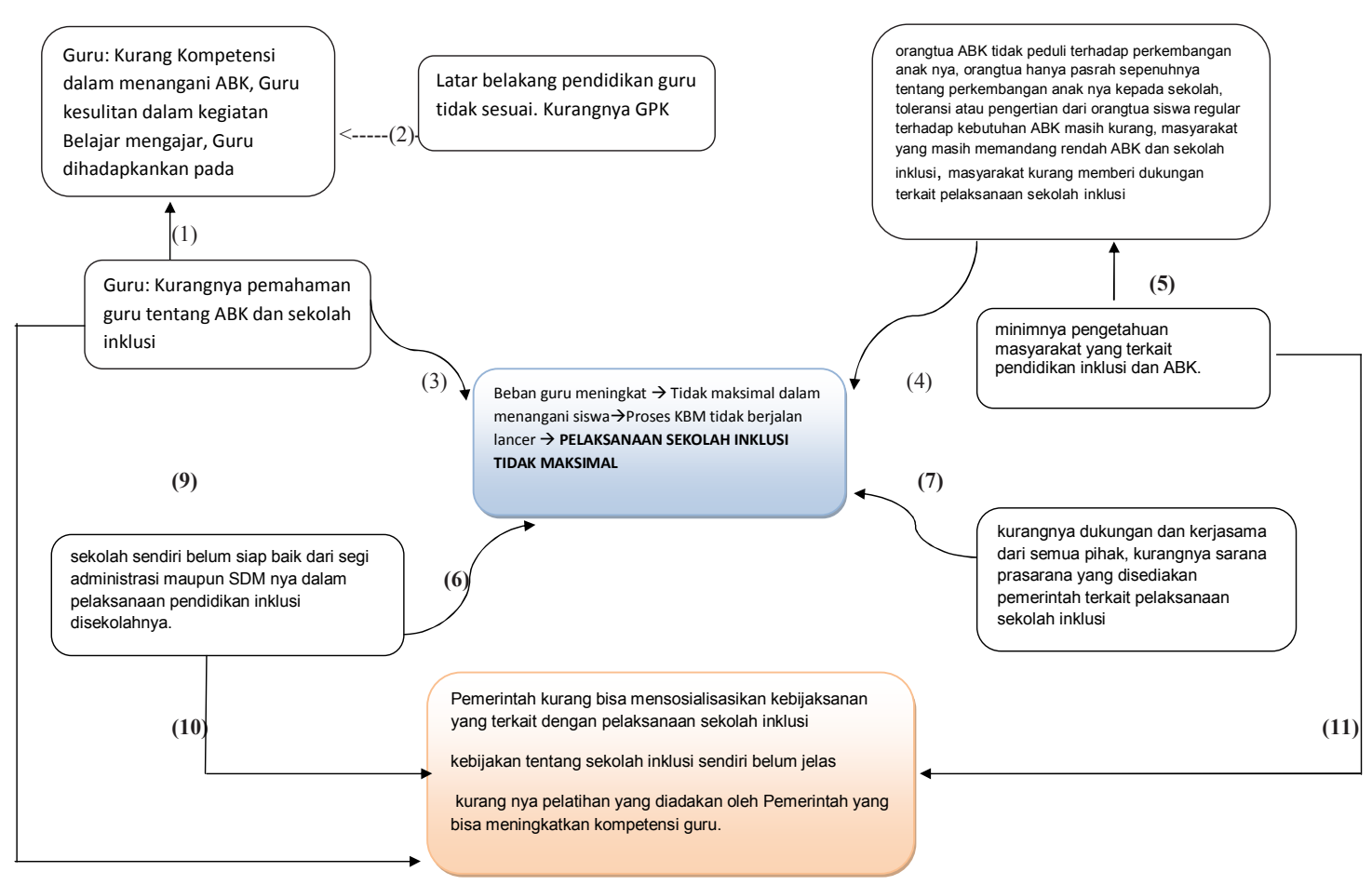

Gambar 1. Dinamika Permasalahan Inklusi

\section{Keterangan:}

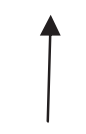

No 1, 5,8 : Menyebabkan

$-----\rightarrow$ No 2 : Secara tidak langsung berpengaruh

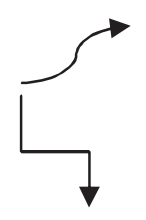

No 3,4,6,7 : Mengakibatkan

No 9,10, 11: Bisa disebabkan oleh

Berdasarkan hasil penelitian, peneliti berusaha merangkum elemen-eleman yang harus terlibat dalam kelancaran sekolah inklusi: 


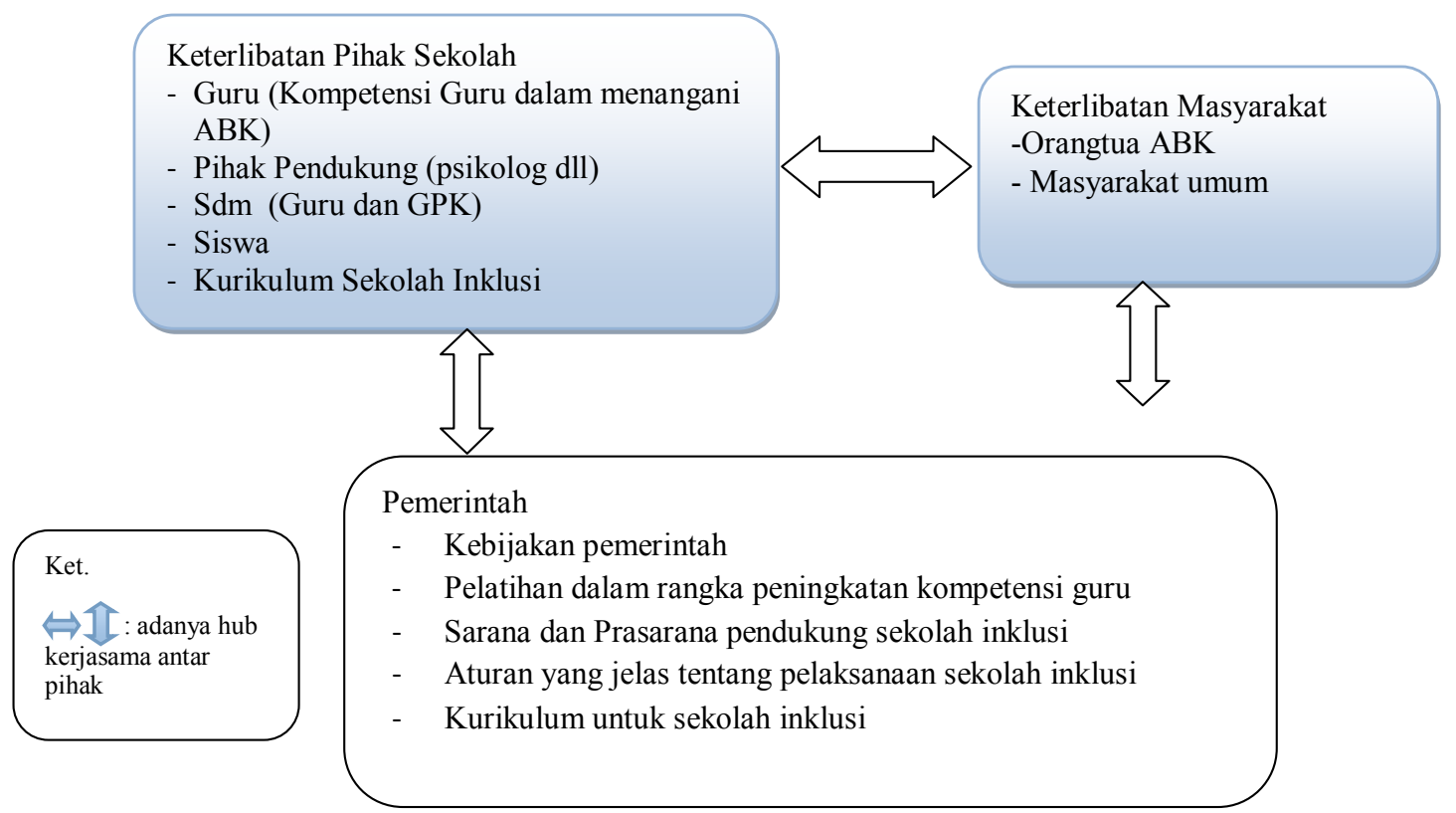

Gambar 2. Eleman-eleman yang harus terlibat dalam kelancaran sekolah inklusi.

Hal ini sesuai dengan yang dikemukakan Sunaryo (2007) bahwa untuk keberhasilan sekolah inklusi perlu melibatkan banyak pihak. Bines (dalam Carrington dan Robinson, 2004) mengemukakan bahwa sekolah inklusi adalah suatu proses yang melibatkan semua staf sekolah dan siswa untuk perkembangannya seperti bagaimana pendekatan mengorganisasi siswa, peran staf pengajar, pendekatan dalam mengajar dan kurikulum. Hal ini juga dikemukakan oleh Giangreco (2013) sekolah juga harus bekerjasama dengan komunitas sekolah seperti guru, guru pendamping kelas, orangtua, siswa, tim administratif sekolah, dan komunitas sekolah untuk memaksimalkan kinerja guru.

Harapan peneliti, bahwa kedepan peneliti lain maupun pemerintah bisa berfokus pada penyelesaian permasalahan yang berkaitan dengan guru, seperti peningkatan pemahaman dan kompetensi guru karena guru adalah ujung tombak dalam pelaksanaan pendidikan. Hal ini juga dikemukakan oleh Hatam (dalam
Carington dan Robinson, 2004) bahwa guru adalah aktor yang penting dalam proses reformasi sekolah. Harapannya jika guru sudah memahami dan mampu melaksanakan pendidikan inklusi di sekolahnya, guru dapat menyalurkan pengetahuannya ke masyarakat melalui orangtua wali murid baik orangtua dari ABK maupun orangtua dari Non ABK.

Pemerintah memiliki tanggung jawab untuk pengembangan profesional/ peningkatan kompetensi guru walaupun terkadang sistem tangggung jawab itu sebagian diserahkan kepada organisasi sekolah, karena sekolah juga memiliki peran untuk melakukan perubahan disekolahnya terutama kepala sekolah (Carrington dan Robinson, 2004), tetapi tidak hanya berfokus kepada guru atapun karyawan dan orangorang yang terlibat dalam pelaksanaan sekolah tetapi juga perlu meningkatkan kepedulian sosial masyarakat terhadap adanya sekolah inklusi. Hal ini menunjukkan bahwa sebenarnya sekolah juga bisa mengembangakan peningkatan kualitas sekolah melalui guru dan pihak-pihak yang 
terlibat didalamnya. Sekolah juga memiliki kewajiban dalam peningkatan kepedulian masyarakat dengan dukungan dari berbagai pihak khusus nya pemerintah.

\section{Simpulan}

Berdasarkan hasil penelitian dapat disimpulkan permasalahan permasalahan yang muncul terkait pelaksanaan inklusi adalah terkait dengan guru, siswa, orangtua, sekolah, masyarakat, pemerintah dan kurangnya sarana prasarana yang mendukung pelaksanaan sekolah inklusi. Hal ini juga dikarenakan kurang adanya kerjasama dari berbagai pihak. Guru merupakan faktor utama dalam proses pendidikan inklusi, tetapi tanpa adanya bantuan dari pihak lain pelaksanaan sekolah inklusi tidak bisa berjalan dengan maksimal, sehingga selain guru yang ditangani, perlu juga menumbuhkan budaya sekolah inklusi baik didalam sekolah itu sendiri ataupun komunitas diluar sekolah tersebut, selain itu kebijakan pemerintah juga sangat menentukan pelaksanaan sekolah inklusi. Penelitian awal ini masih belum mendalam. Penelitian ini mempunyai keterbasan dengan tidak adanya elaborasi data lebih lanjut. Untuk itu penelitian selanjutnya sebaiknya: Melakukan wawancara mendalam atau FGD komprehensif dengan guru, siswa, orangtua, masyarakat dan pemerintah yang terlibat dalam pelaksanaan sekolah inklusi.

\section{Daftar Pustaka}

Afifah, R (2012) .Manajemen Sekolah inklusi masih "Memble".http:// Edukasi.kompas.com

Carrington, S., Robinson, R. (2004) A case study of inclusive school development: a journey of learning.
The International Journal of Inclusive Education 8(2):141-153

Deklarasi Bandung. (2004). www.idpeurope.org.

Depdiknas DIY. (2011). Monitoring Pendidikan Inklusif, belum optimal. http://www.pendidikan-diy.go.id

Giangreco, M.F. (2013). Teacher Assistant Supports in Inclusive Scholls: Research, Practices and Alternatives. Australasian Journal of Special Education.Vol 37.Issue 2 : 93-106. Doi:10.1017/jse.2013.1

Harian Yogya. (2013). Sekolah Inklusi di Yogya Belum Pro Anak Berkebutuhan Khusus. http://www.harianjogya.com.

Kim, U., Shu Yang, K dan Kuo Hwang, K. (2010). Indigenous and Cultural Psychology. Penterjemah: Soetjipto, H.P dan Soetjipto, S.R. Yogyakarta: Pustaka Pelajar.

Kurniaastuti, I. (2010). Dinamika Pencapaian Prestasi Remaja Jawa. Skripsi. Tidak diterbitkan. Yogyakarta: Universitas Gadjah Mada

Mikail, B (2012) Sekolah inklusi belum siap Menampung ABK. http://Edukasi. kompas.com.

Peraturan Menteri Pendidikan Nasional RI Nomor 70 Tahun 2009

Poerwandari, E.K. (2007). Pendekatan Kualitatif untuk Penelitian Perilaku Manusia. Jakarta: Lembaga Pengembangan Sarana Pengukuran dan Pendidikan Psikologi.

Republika. (2013). Jumlah Anak Berkubutuhan Khusus di Indonesia http://m.republika.co.id/berita/ nasional.. 17 Juli 2013 
Rumah ADHD. (2013. Daftar Sekolah Inklusi D.I Yogyakarta. http:// rumahadhd.blogspot.com.

Sadioglu, O. Batu, S. Bilgin, A dan Oksal, A. 2013. Problem, Expectations, and Suggestion of Elementary Teacher Regarding Inclusion. Educational Science: Theory \& Practice. DOI: 10.12738/estp.20133.1546

Schmidt, S \& Venet, M. (2012). Principals Facing Inclusive Schooling or Integration. Canadian Journal of Education 35, 1 :217-238.
Smith, D.J. (2012). Inclusion, School for All Student. Penerjemah: Denis, E. Bandung: Penerbit Nuansa

Sunaryo. (2009). Manajemen Pendidikan Inklusif. Manjpendinklusi.wordpres.

Surat Keputusan Diknas . (2012). Daftar Sekolah Inklusi Di Kota Yogyakarta.

Tukiran., Handayani, T., \& Hagul, P. (1989). Mengkode Data. In, Singarimbun, M., \& Effendi, S (Eds), Metode Penelitian Survai. Jakarta: LP3ES. 